\title{
LEGAL ASPECT OF THE FOREIGN FRANCHISE PROTECTION IN INDONESIAN BUSINESS DEVELOPMENT
}

\author{
Novendri Amiruddin; Rizki Nur Annisa; Bouwris Charisma Putra \\ Faculty of Law, Universitas Sebelas Maret \\ E-mail: novendri_amiruddin@yahoo.com; rizkinurannisao8@gmail.com; \\ boris.charisma@gmail.com
}

\begin{abstract}
This research aimed to learn the Legal Protection For Foreign Franchise which rapidly developed in the business development in Indonesia. It used a doctrinal or normative study which assembles of primary data and secondary data. The concept of franchise business has been become popular topic that provides new breakthrough in the economic dynamics of Indonesia, especially as the form of business development. Considering that franchise is a successful business. Legal protection about foreign franchise business in Indonesia has been by various regulations. However, franchise agreement is main legal aspect in giving legal protection for foreign franchise.
\end{abstract}

Keywords: Legal Protection, Foreign, Franchisee

\section{A. INTRODUCTION}

Rapid and complex of world economic growth gives an impact to economic growth in Indonesia. The economic growth occurs in business activity based on the aspect of business law. The form of the aspect is a profit which becomes purpose and goal of business activity obtained from businessmen. The business which has potential to be developed is franchise business. It can be said that the franchise business has been worldwide. Franchise has grown rapidly in the term of distribution and product marketing. It is because this system has some preeminence which is worth to be considered (Moch Najib Imanullah, 2008:41).

It is marked by cooperation between Indonesian businessmen and foreign businessmen in the field of business which includes franchise business in the franchise agreement. Foreign businessmen bring venture capital and new technology to Indonesia. Indonesia as developing country realizes its limited ability in mastering technology. It is difficult to overcome limited capital ability and limited technology. Therefore, it is necessary to improve the ability of technology transfer. 
One of ways of technology transfer is through franchise agreement. Franchise grows and develops because of necessity in developing a business without spending much money, otherwise they will get income. Business which uses franchise system is a method of goods and services distribution to the consumer. The owner of the method called franchisor, and franchise is given name for parties who have right to use the method. Franchise party is given right and authority in using products, trademarks, and business system created by franchisor (Moch. Basarah dan Faiz Mufidin, 2008: 2).

The important thing of franchise cooperation which is included in the agreement or contract should be understood by each party. Besides, the existence of stability in the contract activity means that rights and obligations between franchise and franchisor should be balanced and should not be unbalanced. In other words, legal equality in the framework of contract freedom must be fulfilled. However, we often encounter inequality in the practice of franchise contract or agreement. It is less profitable for franchise party, i.e., in the termination agreement case, franchisor is the party who has authority to terminate the agreement with the franchise which is caused by for cause. It also happens for terminating franchise agreement. It is the condition where the franchisor does not want to renew the contract when time period of franchise agreement expires, and transferring the business to another party (Rooseno Harjowidgdo, 1993:26).

It is because all of the parties have same circumstance and there is no party who has ability to create principles which support their special condition, and the principle of justice is the outcome of fair agreement and negotiation (John Rawls, 2011:13). In addition, John Rawl had created two principles of distributive justice; they are as follows (John Rawls, 2011:78):

1.the greatest equal principle, it means that every people must have equal rights on the most extensive basic freedom. In other words, the same freedom for everyone.

2. Inequality of social and economic must be well controlled, and we need to pay attention to the principles: (1) the different principle, and (2) the principle of fair equality of opportunity. The second principle ensures the realization of the proportionality of the rights and obligations exchange of the parties. 
In the context of franchise agreement, franchisor and franchise should have equal freedom warranty in order to create equal rights principle. Besides, franchisor and franchise should have a balance in fulfilling their rights and obligations. However, most of franchise agreement is unbalanced because of intellectual property rights. Most of agreements for franchise are a standard agreement which is created by one of intellectual property rights holder and the principle of the contract freedom is unable to be applied yet in the agreement. Actually, standard contract or standard agreement has been known since Ancient Greek. Plato (423-347) had said that food sale practice which its price is unilaterally determined by the seller without considering the differences of food quality.

\section{B. PROBLEM STATEMENT}

Based on the statements above, the important problems which have to be discussed are:

1. How is the existence of foreign franchise in Indonesia?

2. How is the legal protection toward foreign franchise in Indonesia?

\section{RESEARCH METHODS}

The research is a normative legal research. It is a legal research which its data are gained from library research by analyzing a legal issues through legislation, literatures, and other references relating to legal aspects of foreign franchise in Indonesia. Conceptual approach is used to get an explication about legal aspects in the foreign franchise in Indonesia, thus legal protection concept of foreign franchise can be obtained. There are two laws materials which are used in this research, they are; primary legal material and secondary material. Primary legal material takes some legislation which regulate the franchise business. Meanwhile, secondary materials are gained from literatures, journals of law, result of some researches, and articles of law which relate to main problem of this research. 


\section{RESEARCH RESULT AND DISCUSSION}

\section{The Existence of Foreign Franchise in Indonesia}

In the Regulation of the Minister of Trade No. 12/M-Dag/Per/3/2006 about Provision and Procedure for Issuance of Franchise Business Registration License, it stated that "franchise is a bond between franchisor and franchisee, where the franchisee has granted right to run a business using the right of the intellectual property or invention or characteristic of the franchisor's business, and the franchisor gives a reward for the franchisee. The reward is conducted based on the condition set by the franchisor with responsibility to provide operational consultation support continuously. It is provided by franchisor to franchisee". In other words, this regulation explains that franchisor is a business entity or an individual entity which gives a right to another party to use the right of intellectual property or invention or characteristic possessed by franchisor. Meanwhile, franchisee is a business entity or an individual entity which has granted right to use the right of the intellectual property or invention or characteristic possessed by franchisor.

At the beginning, the term of franchise does not exist in the documents of Indonesian Law. It can be understood since the franchise cannot be found in the business culture or tradition of the Indonesian society. However, because of globalization impact which is conquering many fields, the franchise starts to step in the cultural order and legal order of Indonesian society (Tengku Keizerina Devi Azwar, 2005: 1-2). Franchise becomes popular in Indonesia around 1970s when foreign franchise starts to come to Indonesia. The foreign franchises which come to Indonesia are Kentucky Fried Chicken, Swensen, Shakey Pizza, followed by Burger King and Seven Eleven. The word Franchise comes from French language affranchir which means to free. Hence, Franchise means that someone gives freedom to someone else from an obstructive bond and also gives them a freedom to use or make or sell something (Ridwan Khairandy, 2000 : 133). In the business field, franchise means freedom got by a businessman to run a certain business in certain place (Richard Burton Simatupang, 2003: 56). After the term of franchise has become familiar, franchise becomes trending topic among the society, many people also have interest to make it as a business breakthrough. In Indonesia, a business with franchise basis has rapidly developed not only foreign franchise but also local franchise. It can be seen from the facts existed in the society that franchise development is remarkable. It can be seen from the table below (https://suryaadhi.wordpress.com):

Table 1. Franchise Development in Indonesia 


\begin{tabular}{|c|c|c|c|}
\hline Year & $\begin{array}{c}\text { Amount of Foreign } \\
\text { Franchise }\end{array}$ & $\begin{array}{c}\text { Amount of Local } \\
\text { Franchise }\end{array}$ & Total \\
\hline 1992 & 29 & 6 & 35 \\
\hline 1995 & 117 & 15 & 132 \\
\hline 1996 & 210 & 20 & 230 \\
\hline 1997 & 235 & 30 & 265 \\
\hline 2000 & 212 & 39 & 251 \\
\hline 2001 & 230 & 42 & 272 \\
\hline
\end{tabular}

According to the table above, foreign franchise still dominates the franchise in Indonesian. There is a significant difference between local franchise and foreign franchise, i.e., in term of choosing partner or franchisee, the foreign franchise tends to be selective and be careful in choosing their partner, while local franchises ignore those aspects. They tend to choose their partner randomly, as if they prefer quantity than quality (http://www.ukmbiznet.com/franchiselokal-vs-franchise-asing ). Based on the other source of data, it is written that the growth of franchise business in Indonesia is about $12 \%-16 \%$ per Of. There are 331 franchise businesses, which are 293 franchises for foreign franchise and 38 franchises for local franchise (http://www.solopos.com/).

Foreign franchise is more attractive because it has obvious system, worldwide brand, and it is more prestigious. This is the brave history of foreign franchise: nowadays, the franchise is dominated by fast food restaurant franchise. The tendency has been started in 1919 when A\&W Root Beer opens its fast food restaurant. In 1935, Howard Deering Johnson cooperates with Reginald Sprague to monopolize modern restaurant business. Their idea is to let their partner has independent business using same name, food, supply, logo, even same design as their own, and it uses as the exchange of some payments. During its development, this business system experiences various improvements especially in 1950s. Later, after experiencing various improvements, it is known as franchise as business format or it often calls as franchise second generation. The rapid development of franchise system especially in its origin country, Unites State of America, leads the franchise to be favored as the business system in various fields. It reaches 35 percent of all retail businesses in US.

Actually, enthusiasm of local franchise development has appeared. However, local franchise still possesses some weaknesses which make the local franchise unable to compete with foreign 
franchise. Almost all of franchises built by local businessmen are failed. It is not easy to build Franchise business, but it looks advantageous from people who buy the franchise, it can be said that this business is advantageous. The local franchise has some weaknesses, they are (Anke Dwi Saputro, $2016: 1-73)$ :

1. To early in conducting franchise

It usually becomes a reason why the franchise is failed. It is because the franchisor is not ready yet in letting other people use his/her business as the independent business. Sometimes, it is influenced by persuasion of the parties who desire franchising a business, though the business is not ready yet to be franchised. On the other hand, the franchisor is too hasty in approving franchise demand. Therefore, there are many franchises which make the franchisor difficult to control the business, and then one by one the business closed. Moreover, the broken reputation causes the business which has been built die. It can be analogous as a baby who just stands up, but he is forced to run. It can be portrayed in franchise business which is already franchised, though it is still premature. The franchise will also be difficult to develop optimally. The new venture certainly does not have any experiences in the business world. Therefore, it will be better if the business which will be franchised is the business which has survived at least for 5 years.

2. Limited Capital

Sometimes, franchise business becomes a medium for the franchisors to expand their business, and the expansion is conducted by holding franchisee. Their efforts in expanding the business make the franchisor careless in selecting franchise recipient. As the result they fail to choose potential franchise. Then, it will become a trigger of the problem. Franchisee often runs out of fund to continue the franchise business, though the contract is not expired yet. It is what makes franchise die. Running out of capital is driven by wrong financial management, or the profits of the business are not as expected and it leads to disadvantage.

3. Small Business Scale

Local franchise business is often just a cart business which relies on the roadside for the business place. The franchise business that is selected is a business that unfamiliar for the people. Instead of basic needs, almost Indonesian franchisors choose foods or soft drinks as their business.

4. The Product is Seasonal 
Most Indonesians are type of people who often follow new trend. It means that genuine idea is difficult to be found in Indonesia. Therefore, Indonesian Franchise is a business that only goes along with ongoing trend. Then, it will make the product difficult to survive. Besides, the

product cannot be adjusted to all conditions. For example, cold drinks will not gain some profits when rainy season.

\section{Price Competition}

There will be price competition since all Indonesian franchises only go along with ongoing trend. Then, it will become a weapon which can pressure the income and lead the business into disadvantage situation. Besides, price competition can be happened when the franchisee finds out the difficulties to comply the price set by franchisor. It is caused by the rising of the raw material prices. As the effect, the franchisee takes a shortcut by purchasing half of the ingredients from other places, while the half one is purchased from the franchisor. Therefore, it can affect the quality of the goods, then it makes the consumer disappointed and the franchisee will lose his/her consumer. Then, it makes the franchise business bankrupt.

6. Human Resources Problem.

Human resources in Indonesia are often considered as human resources who are lack of professionalism. There are many incidents where a chef steals other people receipts or a chef who randomly asks for countless salary. Franchise business is a business demanded by most businessmen who are busy with work in their office. It causes the businessmen do not possess specific skill and they entrust the business management to the chef. Then, that belief causes the chef makes a fool of the owner.

7. Unorganized system

The system owned by local franchise is less qualified compared to foreign franchise. This system still cannot be considered as sophisticated system because it is still in the intermediate level. Then, it causes the operational work and financial are not well organized. The effect is the failure of the franchise business.

\section{Intellectual Property Ownership Conflict}

There are some problems caused by seizure of intellectual property. Franchisor often forgets to registry the brand, patent, trade secret, even to registry the franchise, though it is an important thing to do in the world of franchise business. The franchisee will get good opportunity to take over the franchise business, when the franchisor focus on the franchise 
expansion which makes them forget to conduct their legal protection obligation for protecting themselves. There are many cases resembling to the case above, and ironically the intellectual property often lost from the franchisor's possession.

\section{Betrayed by Business Partner}

Backbiting from the business partner is often committed using business cloning. In other words, the franchisee imitates his/her franchisor's business and runs his/her own business using same business. Besides, the franchisee also hides the fact that he/she opens other franchise business to avoid payment of royalty cost which must be paid to the franchisor.

Based on the causative factors of bankruptcy of the local franchise business, we can see on the whole that local franchise business is less prestigious. As the businessmen, we obviously pursue the profit and well organized system which give us certainty to be able to compete in the trade world.

Actually, the existence of foreign franchise in Indonesia does not give bad effect to the local franchise. Foreign franchise also gives some advantages to the local franchise. The advantages are, as follow;

1. Foreign franchise business in Indonesia must give knowledge about global business model to Indonesian businessmen. It is actually good education for our local business knowledge. Therefore, the local franchise can participate in the qualified franchise to compete with foreign franchise.

2. Foreign franchise, which has well-prepared system, will provide higher chance of success and the effect will give better sales turnover (especially in economic) for turnover of Indonesia economic.

3. The impact on the labor absorption will be better. The existence of foreign franchise can decrease the unemployment in Indonesia. It can also become a medium for labor absorption and increase the welfare of Indonesian citizens.

4. The impact to the technical industry learning is better to be continued to technology transfer activity. Based on the foreign technology which has better quality, it should become knowledge for the societies of Indonesia develop local franchise business.

5. The impact in trading activity toward the local supplier will be outstanding. It will change the supplier to be global supplier. Imagine that the local supplier which has good track record cooperate with international brand. 
6. The rising of foreign franchise or multinational business in Indonesia gives an impression that Indonesia is a part of developed country, and it will repeal the impression that Indonesia is a least developed country. The more international brands enter to Indonesian market will give trust to foreign investor to invest their assets in Indonesia. The impact will be economic progress of Indonesia.

Nowadays, franchise business has been popular in Indonesia. Franchise is a good business sector. We can find that business around us, not only local franchise, but also foreign franchise. Franchise is business sector where we can find a borrower's name and royalty recipient. Considering the existence of companies in the business world, we can find difficulties in establishing new business because the competition among the companies cannot be avoided. Therefore, some newbie businessmen chose franchise business as their business. There are many foreign franchises in Indonesia which engage in various fields, such as education, retail, automotive, and culinary. The existence of foreign franchise will obviously give an impact to local business, thus, Minister of Trade make a rule to limit the amount of foreign franchise.

There are some foreign franchises which are popular in Indonesia, especially in the food and beverage fields. One of those foreign franchises which engage in the food and beverage is MC Donald. There is also Burger King which has same field as MC Donald. The other foreign franchises are Pizza Hut, Baskin Robins, Yogen Fruzz, Dunkin Donuts, Round Table Pizza, and Jollie Bee.

Foreign franchises which engage in beverage field are Coca-cola and Pepsi. There are also Green Spot and Gatorado. Furthermore, foreign franchises which engage in café or restaurant or bar are Hard Rock, Black Angus, Red Lobster, Fashion Café, Hong Bin Lao, etc. The other foreign franchise which is popular enough is 7-eleven, it engages in restaurant field (http://bisnisfranchiseindonesia.com/).

The franchises which engage in non food and beverage are Gakken Educational Co. Ltd and Schida Educational Institute Inc. Both of those institutions are the institution come from Japan. There is also online trading academy which come from California, US. It is an online education service. For those who love cooking, there is Young Chefs International which also comes from America. There is Crestcom International, LLC from America. It is a field that engages in management and employee training service. Other foreign franchises which engage in education 
are Dale Carnegie \& Associates, Inc which comes from New York, and Global enrichment center Pte Ltd which engages in education service of math money.

Foreign franchise in retail field is DKH Retail Limited which comes from England. There is also Coas Fashion Limited which engages in accessories field. The other popular retail franchise is Karen Millen which engages in fashion and accessories field. Next, there is Oasis Fashion Limited and Ne Look Retailers Ltd which both of them come from UK. Almost foreign franchise in Indonesia are successful, it can be a lesson for us. Besides, it makes us understand that foreign franchises have well-prepared business system which makes them success in foreign country.

\section{Legal Protection for Franchise in Indonesia}

Freely, franchise can be defined as privilege which is bind up and/or given by franchisor to franchisee with obligations or payments. In the business format, definition of franchise is business regulation with granting usage rights of brand system by franchisor to independent party or franchisee to sell product or service based on the agreement (Anonymous , 2013).

Queen said that the definition of franchise is; franchise is a method in expanding business and marketing. It means expanding market and distribution and service by dividing marketing standardization and operational. Franchise holder who buys certain business gets benefit from the customer consciousness on brand name, qualified system, and other service provided by the franchisor (J. Quenn, 1993: 4). Since the enactment of Government Regulation Number 42 Of 2007 about Franchise, especially in article 1 point 1 of Government Regulation Number 42 Of 2007, franchise means privilege which is possessed by independent party or business entity toward business system with business characterization. It uses to market goods and/services which its success has been proven. It can be used by other party based on the franchise agreement. This definition is valid for formal jurisdiction in Indonesia.

Gurnick stated in Margono and Angkasa (Margono. Suyud dan, Amir Angkasa, 2003), franchise is a model which is the most popular business for businessmen because it has effective method in supplying a certain model to the market by buying rights to copy intellectual property owned by franchisor. It can be brand name, product, and secret information by giving support to franchisee such as giving training support, marketing strategy, advertising group, and purchasing regulation. Therefore, the existence of franchise business has significantly developed. It has also got the recognition from senior businessmen and business law expert, although the legislation does not exist yet. However, since 1983, through Jurisprudence of Supreme Court Number 
3051/K/Sip/1981 date $26^{\text {th }}$ December 1983 in the case of Gold Bond brand initiates in giving brand license in Indonesia. it is because one of the franchise legal aspects is the usage of license brand by licensor to the licensee. Therefore, before the enactment of Jurisprudence of Supreme Court, legal protection for franchise is conducted through franchise contract which is created by other parties using Third Book about Engagements and Articles contained in Civil Code or Burgelijke wet Boek $(B W)$. It regulates the agreement, such as in Article 1320, Article 1338, and Article 1365 of the Civil Code.

As the rapid increase of the franchise usage which is used as the business model, the businessmen will prosecute the government to renew the regulation used to legal protection for franchise in Indonesia:

1. Agreement as basic law, Civil Code article 1338 (1), 1233 up to 1456 of Civil Code; the parties are free to conduct any business as long as it is not against to applicable law, custom, courtesy, or other matters relate to public order, the terms of agreement validity, etc.

2. Agency law as the basic law, Trade Code (broker \& commissioner), administrative provisions such as Department of Industries, Trade, etc. It is often determined firmly in the franchise contract that between franchisor and franchisee does not have agency relationship.

3. Brand Law, Patent, Copy Rights as basic law; due to involvements of trademark and logo owned by franchisor in the franchise business, plus if there are some possibilities that there is an invention by franchisor. the invention that can be claimed. Law number 15 Of 2001 About Trademark, Law Number 14 Of @001 About Patent, Law Number 28 Of 2014 About Copy Rights.

4. Law of Foreign Investment as the basic law; if the franchisor will open an outlet in certain Country, excluding the franchisor's country, it will be better if it is consulted to legal adviser about various possibilities and alternatives which may be taken by the franchisor and the most beneficial. Franchise is chosen to avoid a restriction for a foreign company when they will take action through direct investment.

5. Government Regulation Number 42 Of 20017 about franchise. In the Government Regulation, all of activities which relate to franchise held in Indonesia regulated by the Government. In the case of criteria which can be categorized as franchise, provision relating the franchise agreement, obligation of the franchisor, registering prospectus of franchising offer, registering franchise agreement, training and supervision, and sanction. Franchise agreement will create 
rights and obligations, though there is a principle of freedom of contract. According to Government Regulation Number 42 freedom of contract, Government Regulation Number 42 Of 2007 about franchise, it regulates some obligations which is fulfilled by the parties. In Article 8 , it is stated that franchisor must the franchisee training, supervising in management operational, marketing, research, and development continuously. It includes conducting quality control and evaluation to the business conducted by the franchisee (Moch Najib Imanullah, 2011: 12).

6. Regulation of Minister of Trade Number 12/ about M-DAG/Per/3/2006 about Provision and Procedure for Issuance of Franchise Business Registration License. In the regulation of Minister of Trade, it is explained about procedure for issuance of franchise business registration license which must be possessed by franchisee. Besides, it is also explained about the obligation of the franchisor, and local and foreign franchisee to registry franchise agreement and prospectus of franchise offers to domestic general of trade department, and for local franchise can registry to local trade department.

7. Regulation of Indonesian Minister of Trade Number 53/M-DAG/PER/8/2012 about franchise implementation. In the regulation of Minister of trade which regulate the franchise implementation which is particularly rule about franchise implementation set by franchisor given to local franchisee existed.

8. Regulation of indonesian Minister of Trade Number 57/M-DAG/PER/9/2014 about Amandement to Regulation of the Minister of Trade number 53/M-DAG/PER/8/2012 about Franchise Implementation. This regulation is the changing rule from former Minister of Trade, there is an Article which explain about master franchise agreement.

Foreign franchise which has been used as the business model by the society attracts the attention of lawyers, because it is not only regulated by those rules, but it also relate to some other laws in both civil field and non-civil field. However, the relation may not be realized yet by the parties, because those regulations do not regulate main issues, such as condition of the agreement, though it regulates the complements which cannot be ignored in the legal aspect of franchise. the regulations arre, as follow:

a. Franchise Relation with Law Number 13 Of 2003 about Employment.

Employment law has a rule to guarantee social-economic position of the employment and the direction which must be taken in regulating social-economic relationship, protecting 
fundamental rights of the employment, such as right on wages and right on safety and healthy. Thus, when looking at the franchise agreement which will employ other people, it will create work relationship which creates rights and obligation between them. Therefore, the employment law through Law Number 13 Of 2003 binds the businessmen in the franchise agreement. Besides, the franchise agreement is also bind by Law Number 5 Of 1981 about mandatory report of the employment in the company.

b. Franchise Relationship with Law in the Tax field

There is an outstanding transaction in this franchise business. It will bind the franchise agreement, they are; transferring service from franchisor to franchisee conyains usage of trademark right, transferring taxable goods, income which is accepted in the business activity as income tax and value-added tax.

c. Franchise Relationship with law Number 3 Of 1982 about Obligation on Registering a Company.

On the Article 1 Letter a law Number 3 Of 1982, it is explained that list of companies is official list held under the provision of Law and the provision of implementation of Law and contain things that must be registered by each company and it will legalized by the competent authorities from the Company Registration Office. Besides, on the article 7 and 8, it is mentioned that the company which must be registered is every company which has position and run their business in Indonesia. According to applicable law, it includes branch office, auxiliary office, subsidiaries and agents, and representative of companies which have authority to hold agreement. Therefore, franchise agreement binds the company's registration, because franchise agreement will create new independent company.

d. Franchise Relationship with Law Number 5 Of 1999 about Prohibition to Monopoly Practice.

In relation to Law of Prohibition to Monopoly Practice, it does not exclude to not enforce the provisions prohibited by Law which relate to franchise as mentioned in article 50b. Next, KPPU releases a Regulation of KPPU Number 6 Of 2009 about Exclusion Guidelines for Implementation of Law Number 5 Ofs 1999 relates tofranchise in order to prevent misapplication of the provisions.

\section{E. CLOSING}

\section{Conclusion}


Economy development is happened in the business activity which is based on the business legal aspect in the form of profit which becomes purpose and goal of business activity which is got from businessmen. Therefore, the process which supports the business activity needs to be considered in the agreement. It is meant to become foundation in all business activities. It is marked by the cooperation in the field of business, it includes franchise in the franchise agreement. One of the technology transfers is through franchise agreement. Business with franchise system is method of goods and services distribution to the customer. The owner of this method called franchisor, and the party who gets the rights to use the method is franchise. Franchise is given rights and authorities to use products, trademark dam business system which is created by franchisor. The important thing of franchise cooperation which is written in the agreement should be understood by each party and there is a balance in contract. It means rights and obligations between franchise and franchisor should be balanced. In other words, legal equality in the framework of freedom should be fulfilled.

\section{Suggestion}

Government has certainly done nay reformations in the regulation about franchise, but the legal aspect which has been applied by the government is not a warranty for franchisor and franchisee. Government supervisions are required to agreement between franchisor and franchisee, thus franchisee as the license recipient does not harmed because of unclear agreement. Therefore, socialization is required to people who will join to franchise business.

\section{BIBLIOGRAPHY:}

Basarah, Moch., dan H.M. Faiz Mufidin.2008. Bisnis Franchise dan Aspek-Aspek Hukumnya. Bandung. PT. Citra Aditya Bakti.

Dwi Saputro,Anke. 2016. Penyebab Matinya Waralaba. Jakarta.Elex.

Fuady, Munir. 2001. Hukum Kontrak (Dari Sudut Pandang Hukum Bisnis). Bandung. PT. Citra Aditya Bakti. 
Ibrahim, Johannes, dan Lindawaty Sewu. 2004. Hukum Bisnis Dalam Perspektif Manusia Modern. Jakarta. PT. Refika Aditama.

Keizerina Devi Azwar, Tengku. 2006. Perlindungan Hukum Dalam Franchise. Repository USU.

Khairandy, Ridwan. 2000. Perjanjian Franchise sebagai Sarana Alih Teknologi. Pusat Studi Hukum UII Jogyakarta bekerjasama dengan yayasan Klinik Haki Jakarta.

Margono. Suyud dan, Amir Angkasa. 2003. Komersialisasi Aset Intelektual Aspek Hukum Bisnis, Jakarta, Grasindo.

Moch Najib Immanullah. 2008. Kontribusi Huku Terhadap Waralaba di Indonesia, Yustisia Edisi 74 Mei-Agustus 2008 Tahun XIX.

Moch Najib Immanullah. 2011. Urgensi Pengaturan waralaba dalam Undang-Undang. Yustisia Edisi 83 Mei-Agustus 2011 Tahun XXI.

Naihasy, Syahrin, Hukum Bisnis ( Business Law ), Mida Pustaka, Yogyakarta, 2005.

Queen, Douglas J., Pedoman Membeli dan menjalankan Franchise : Tuntutan langkah Demi Langkah Menuju Keberhasilan Suatu Franchise, PT. Elex Komputindo, Jakarta, 1993.

Rawls John. 1971. A Theory Of Justice. Hardvard: Belknap Press.

Richard Burton Simatupang, Aspek Hukum Dalam Bisnis, Rineka Cipta, Jakarta, 2003.

Rooseno, Harjowidigdo, Perspektif Pengaturan Frenchise, Makalah Peraturan Ilmiah Tentang Usaha Frenchise dalam Menunjang Pembangunan Ekonomi, Jakarta: BPHN, 1993.

Sutedi, Adrian, Hukum Waralaba, Ghalia Indonesia, Jakarta, 2008.

\section{Internet :}

https://suryaadhi.wordpress.com/2015/06/26/makalah-hukum-dagang-tinjauan-yuridis-waralaba/ diakses 1 Desember 2016, pukul 13.11 WIB 
http://www.solopos.com/2016/05/17/bisnis-waralaba-tumbuh-pesat-di-indonesia-tapi-mayoritaswaralaba-asing-720330. diakses 1 Desember 2016, pukul 14.03 WIB

http://bisnisfranchiseindonesia.com/, diakses 3 Desember 2016, pukul 11.01 WIB http://www.ukmbiznet.com/franchise-lokal-vs-franchise-asing/, diakses 3 Desember 2016, pukul 17.01 WIB 